\title{
Preliminary Report on LLNL Mine Seismicity Deployment at the Twentymile Coal Mine
}

W. R. Walter

RECENTED

S. L. Hunter

L.A. Glenn

FEB 201930

OSTI

This paper is submitted as

CTBT Seismic Monitoring Project Task S7.2, Deliverable \#2

January 1996

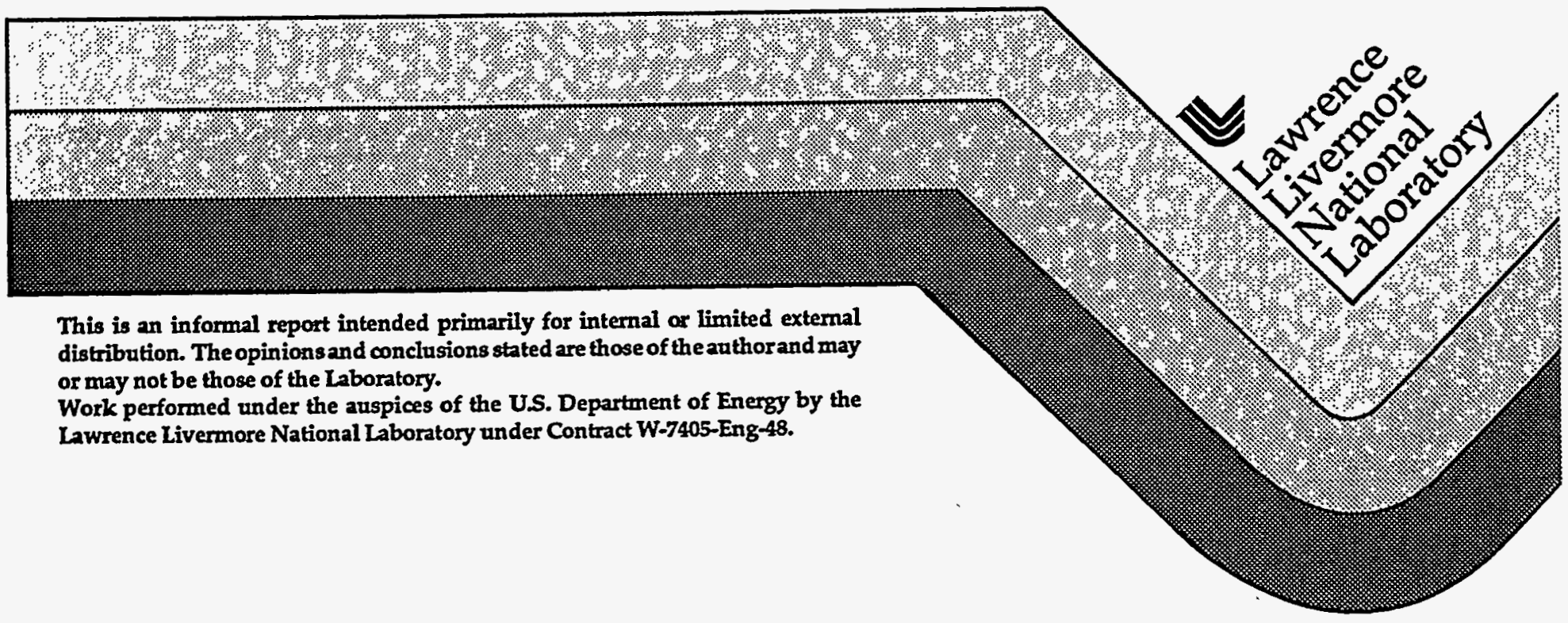




\section{DISCLAIMER}

This document was prepared as an account of work sponsored by an agency of the United States Government. Neither the United States Government nor the University of California nor any of their employees, makes any warranty, express or implied, or assumes any legal liability or responsibility for the accuracy, completeness, or usefulness of any information, apparatus, product, or process disclosed, or represents that its use would not infringe privately owned rights. Reference herein to any specific commercial product, process, or service by trade name, trademark, manufacturer, or otherwise, does not necessarily constitute or imply its endorsement, recommendation, or favoring by the United States Government or the University of California. The views and opinions of authors expressed herein do not necessarily state or reflect those of the United States Government or the University of California, and shall not be used for advertising or product endorsement purposes.

This report has been reproduced directly from the best available copy.

Available to DOE and DOE contractors from the

Office of Scientific and Technical Information

P.O. Box 62, Oak Ridge, TN 37831

Prices available from (615) 576-8401, FIS 626-8401

Available to the public from the

National Technical Information Service

U.S. Department of Commerce

5285 Port Royal Rd,

Springfield, VA 22161 
CTBTR\&D Program: LLNL Seismic Monitoring Project Task S7.2 - Field study to improve understanding of mine induced seismicity

\title{
Preliminary Report on LLNL Mine Seismicity Deployment at the Twentymile Coal Mine
} (Deliverable \#2)

\author{
W. R. Walter, S. L. Hunter, and L. A. Glenn \\ Lawrence Livermore National Laboratory \\ January 1, 1996
}

\begin{abstract}
This report summarizes the preliminary results of a just completed experiment at the Twentymile Coal Mine, operated by the Cyprus Amax Coal Company near Oak Creek, CO. The purpose of the experiment was to obtain local and regional seismic data from roof caves associated with long-wall mining activities and to use this data to help determine the effectiveness with which these events can be discriminated from underground nuclear explosions.
\end{abstract}

\section{Introduction}

The sudden collapse of man-made underground cavities has generated seismic signals as large as magnitude 5.4. Collapses are just one of the many types of mining-associated seismicity which need to be identified and distinguished from potential clandestine nuclear explosions under a future Comprehensive Test Ban Treaty (CTBT). Collapses are of concern for seismically monitoring a CTBT for a number of reasons. First, they can look like explosions when using some seismic discriminant measures, such $M_{s}: m_{b}, M_{o}: m_{b}$ and depth. Second, underground nuclear explosions themselves produce cavities that might collapse, possibly aiding in the detection of a clandestine event. Finally any seismic event, including collapses, occurring in the vicinity of a known or suspected cavity would come under special scrutiny because of the concern that such cavities could be used to evasively decouple a clandestine test. For these reasons collapses in active or former mining regions have the potential to be false alarms under a CTBT. .In order to

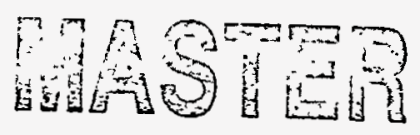


better understand these types of events LLNL has an active field program to study mining seismicity.

The largest seismic collapse events $(M>3.5)$ tend to be accidental failures in large room and pillar mines (e.g. Pechmann et al., 1995, Taylor et al. 1994). Considerable effort by miners is usually taken to avoid these events for obvious reasons, and such accidents tend to be relatively rare. However, in certain instances, as in long-wall mining, rock-burst-like collapse of the roof panel is an integral part of the mining technique. While these events are smaller $(M=2-3.5)$ than the big accidents they are also more common and part of the routine operation of the mine. It has been noted (e.g. Taylor et al., 1994) that, because mined cavity collapses are shallow and may not have double-couple (earthquake) mechanisms, some of their seismological features are similar to those of underground explosions and it might be difficult to discriminate one from the other, thereby providing possibilities for evading a ban on the underground testing of nuclear explosives. The evader might either claim the explosion was a collapse event or conduct the explosion simultaneously with the collapse, with the intent of hiding the explosion in the overall event coda.

To learn more about the seismic characteristics of long-wall collapse events, we designed and conducted an experiment in cooperation with the Cyprus Amax Twentymile Coal Company at their Foidel Creek Coal Mine. This mine held the world record for monthly underground coal production $(534,557$ tons in September 1994), and set a new world record during our experiment. The experiment consisted of an 11-station seismic deployment, covering the immediate vicinity of the mine and extending to a distance of roughly $100 \mathrm{~km}$. We recorded all the seismicity associated with the mining of a new panel, beginning with the "first cave" of an estimated $25,000 \mathrm{~m}^{2}$ roof panel, and continuing with the monitoring of aftershocks and subsequent collapses for an approximate 3 month period.

\section{Mine Operation}

The Cyprus Amax Twentymile coal mine is an underground long-wall coal mine. The operation completely excavates the 3 meter ( 10 foot) high Wadge coal seam at a depth of approximately $350 \mathrm{~m}$ (1100 feet) underground in $244 \mathrm{~m}$ ( $800 \mathrm{foot}$ ) wide panels. The roof rock above the coal seam is supported hydraulically in the immediate vicinity of the area of active mining. The entire mining machinery moves forward as the coal is removed and the region behind the active mining is allowed to collapse as shown in Figure 1. It is believed that the softer shale rocks collapse until reaching the more competent sandstone layers, which can support more weight. It is the failure of these sandstone layers that we believe leads to the $M \approx 2-3.5$ seismic events which have been detected by the U. S. Geological Survey 
station $160 \mathrm{~km}$ away in Golden Colorado. These seismic events do not cause significant air waves.underground and do not generally impede the operation of the mine. After failure of the sandstone layers, the collapsed zone spreads up to the surface, where the ground above the region that has been mined eventually subsides about $1.4 \mathrm{~m}$ ( 4.5 feet). The lack of easily visible surface subsidence and absence of impact on the mine operation mean that ground inspection and overhead imagery may shed little light on the nature of a seismic event coming from mines of this type (see Figure 2) without more careful study. To better understand the nature of the seismic events coming from this mine we carried out a seismic field study.

\section{Seismometer Deployment}

The seismometers were deployed in two groups. A close-in array of strong motion accelerometers were deployed above the surface where the roof collapse was expected to occur as shown in Figure 3. A second group of velocity sensors were deployed in a line heading towards AFTAC's permanent array in Pinedale, Wyoming and one sensor on a line towards a USGS permanent station in Golden, Colorado as shown in Figure 4.

The ring of strong motion sensors used 3-axis Wilcoxon piezoelectric accelerometers in order to capture the large amplitude and high frequency components that were expected close-in. There were three sites in the ring, roughly spaced 500 meters from the expected center of roof collapse. There was one forcebalance accelerometer at the center. These sites were recorded with Reftek digitizers, operating in event-triggered mode. The close-in array was designed to provide information on the location, time history and first-motion mechanism of the mining induced events.

The line of sensors heading towards the Pinedale array in Wyoming had sensors at distances of 5.5, 8, 10.5, 20 and $100 \mathrm{~km}$ from the center of the event site. AFTAC's Pinedale array station is about $337 \mathrm{~km}$ from the mine. The first three stations used S-6000 seismometers and the furthest two sites used Guralp 40T and ESP seismometers; all 6 sites employed Reftek digitizers operating in continuousrecord mode. This line of stations was designed to provide information on regional phase propagation out to the Pinedale array.

The station on a line towards a permanent station GOL in Golden, Colorado was $20 \mathrm{~km}$ from the event site. This site used a Guralp seismometer and a Reftek digitizer operating in continuous-record mode. This station also helped to evaluate regional phase propagation out to GOL. Together with the $20 \mathrm{~km}$ station at the Pinedale azimuth, the two $20 \mathrm{~km}$ Guralp seismometer stations gave good broadband response and some azimuthal coverage for waveform modeling studies to better 
understand the source mechanism of the mining induced events.

\section{Seismic Events Recorded}

We searched through the first three months of data and picked out the largest events that triggered the close-in stations. The dates and times of the five events larger than $\mathrm{ML}_{\mathrm{L}}=2$ are given in the table below.

\begin{tabular}{|l|l|l|}
\hline Date & Time (UT) & M $_{\text {(Coda) }}$ \\
\hline August 5, 1995 & $23: 49: 50.0$ & 2.0 \\
August 25, 1995 & $12: 51: 24.6$ & 2.8 \\
September 6, 1995 & $2: 57: 49.4$ & 2.6 \\
October 2, 1995 & $12: 38: 12.0$ & 2.9 \\
October 5, 1995 & $01: 18: 13.5$ & 2.8 \\
\hline
\end{tabular}

The August 25th event was large enough to be recorded at the LLNL station KNB about $640 \mathrm{~km}$ away. Having calibrated that station previously (e.g. Mayeda and Walter, 1996) we were able to determine an $\mathrm{M}_{\mathrm{L}}$ (Coda) of 2.8 for the event. The other event magnitudes were determined relative to the August 25th event. The timing of the first arrivals at the close -in arrays was consistent with the events being located close to the currently active mining panel and very shallow in depth $(<500 \mathrm{~m})$. A more accurate location requires more refinement of the shallow velocity model for the region and will be the subject of future work. There were many other well recorded events that appear to have magnitudes less than two. The dates and times of the larger ones are given in Appendix A.

A comparison of the seismograms of the five largest events and their spectra is given in Figure 5. Note that all the traces show an initial downward (negative) motion and much similarity in their shapes. With the exception of the August 5th event they also have quite similar spectra. The spectra show peaks near $1 \mathrm{~Hz}$, which in the time domain can be seen as the result of the slowly traveling $(<1.7 \mathrm{~km} / \mathrm{s}$ group velocity) large amplitude $\mathrm{Rg}$ phase coming in after 12s. These Rg phases are commonly seen in local records from very shallow sources of seismicity. In fact the spectral peak can still be observed at more distant stations by examining the coda (e.g. Mayeda and Walter, 1995).

The major difference observed between events is the change in spectral content between the August 5th event and the subsequent large events. Since the August 5th event was the first large event, occurring only 5 days after mining on the current panel began, it seems plausible that the August 5th event had a different 
depth, mechanism or time function than the latter events. More analysis will be required to determine the cause of the frequency difference.

\section{Collapse Events}

To gain a better physical understanding of the cause of the mining-induced seismic events we examined their source mechanisms using two techniques. First we used the standard technique of examining the first motion direction of the ground using the close-in stations. Second, we employed the more sophisticated technique of waveform modeling using the 3 component broadband stations $20 \mathrm{~km}$ away (e.g. Walter, 1993).

The August 25th event was well recorded at all of the close-in accelerometers and, as seen in Figure 6, shows clear downward (negative) motions at all of the stations. The event appears to have been shallowly located under the array between the stations NE500, N500 and GZ. This location and first motion profile is consistent with either a normal earthquake mechanism (top block slides down a dipping fault relative to the foot block) or a collapse mechanism (block collapses vertically under gravity) as described by Pechmann et al, 1995. This first motion is not consistent with explosive sources or other simple types of earthquake mechanisms. All five $\mathrm{M}_{\mathrm{L}}>2$ events have similar first motions at the close-in sites.

Waveform modeling can distinguish between normal earthquakes and collapses but requires knowledge of the velocity structure to calculate the synthetic seismograms. We determined a preliminary velocity structure for this region as follows. We started with the Southwestern Wyoming model described by Pechmann et al (1995) which was based on Prodehl (1979). The top kilometer was modified based on information received from the Twentymile mine. For the layers above the coal seam we used the measured values of Young's modulus provided from the mine, along with our assumptions about Poison's ratio, to determine the shear modulus for the layers. Along with density measurements and estimates we could then determine the $P$ - and $S$-wave velocities. The $P$ - and $S$-wave velocities of the two layers below the coal seam were adjusted by trial and error modeling to give the timing and dispersion observed in the data. This preliminary velocity model for the path from the mine to the PD20KM site is given in the table below: 


\begin{tabular}{|l|l|l|l|l|l|}
\hline $\begin{array}{l}\text { Layer } \\
\text { Thickness } \\
(\mathrm{m})\end{array}$ & $\begin{array}{l}\text { P-wave } \\
\text { Velocity } \\
(\mathrm{km} / \mathrm{s})\end{array}$ & $\begin{array}{l}\text { S-wave } \\
\text { Velocity } \\
(\mathrm{km} / \mathrm{s})\end{array}$ & $\begin{array}{l}\text { Density } \\
(\mathrm{g} / \mathrm{cm})\end{array}$ & $\begin{array}{l}\text { Poisson } \\
\text { Ratio }\end{array}$ & $\begin{array}{l}\text { Rock Unit } \\
\text { Description } \\
\text { (from mine) }\end{array}$ \\
\hline 64 & 1.58 & 0.90 & 2.2 & 0.27 & Holderness \\
80 & 1.88 & 1.07 & 2.2 & 0.26 & Sandstone \\
174 & 2.18 & 1.24 & 2.2 & 0.30 & Marine Shale \\
14 & 2.41 & 1.38 & 2.3 & 0.26 & Sandstones \\
668 & 3.50 & 1.99 & 2.3 & 0.26 & \\
1000 & 4.00 & 2.28 & 2.4 & 0.26 & \\
1000 & 4.80 & 2.73 & 2.6 & 0.26 & \\
2000 & 5.20 & 2.96 & 2.7 & 0.26 & \\
2000 & 5.70 & 3.25 & 2.7 & 0.26 & \\
2000 & 6.00 & 3.42 & 2.7 & 0.26 & \\
5000 & 6.20 & 3.53 & 2.7 & 0.26 & \\
8000 & 6.60 & 3.76 & 2.7 & 0.26 & \\
14000 & 6.80 & 3.87 & 2.7 & 0.26 & \\
2000 & 7.10 & 4.04 & 2.88 & 0.26 & \\
2000 & 7.40 & 4.21 & 2.88 & 0.26 & \\
$\infty$ & 7.90 & 4.37 & 3.33 & 0.28 & \\
\hline
\end{tabular}

We used waveform modeling techniques to try to distinguish between the two types of mechanisms suggested by the first motion data. In our waveform modeling we calculated synthetic seismograms using a reflectivity code (George Randall, written communication) and compared them to the data for each of the possible mechanism types. We narrowed down the possibilities from the first motion data to gravity driven collapse or a normal fault. Noting the lack of energy on the transverse components, we tried mechanisms that were nearly nodal for Love waves at the two stations PD20KM and G20KM. The comparison between the data and synthetics at station PD20KM for the largest event on October 2, 1995 is shown in Figure 7. While the fit is not perfect, the gravity driven vertical collapse clearly fits better than the normal earthquake mechanism. This indicates that the point source mechanism is different from normal earthquakes and similar to some large accidental collapses. While this may complicate efforts to discriminate these events from potential underground nuclear explosions (e.g. Taylor 1994), more work needs to be done to evaluate the discrimination behavior of these collapse events 


\section{Regional Phase Propagation}

An important aspect of using regional phases to identify event source types is understanding and predicting how the phases develop and propagate. In our experiment, the location of the source of seismic waves was known ahead of time so that we could deploy a number of seismometers in a line from the source to the permanent regional station. This allowed the study of the initial genesis and propagation of these regional phases. An example of this regional phase development is shown in the record section in Figure 8. Note in particular the prominent, large amplitude, very slowly traveling short period $\mathrm{Rg}$ phases seen at distances of $20 \mathrm{~km}$ and less, that were discussed earlier. By $100 \mathrm{~km}$ this energy appears to have spread and scattered out into the coda. Note also that the regional phases commonly used in discrimination--Pn, Pg and Lg (Walter et al. 1995)--do not fully develop until the seismic waves are more than $100 \mathrm{~km}$ from the source.

\section{Future Work}

The Twentymile Coal Mine experiment has collected an extremely high quality and important dataset. In addition to the mine collapses and other mineinduced seismicity, the continuously recording seismometers recorded local earthquakes, explosions detonated for the Lithoprobe project, and seismicity from other mines in the area. We plan to use these additional sources, along with data recorded by the permanent stations at Pinedale, Wyoming and Golden, Colorado, in a future discrimination study. The location of earthquakes, explosions and mine collapses, all in the same region, offers an ideal dataset to test our discrimination algorithms. Seismic collapse events are part of the routine operations at a number of mines all over the world. It is crucial that we learn how to identify these types of events and prevent their confusion with the signals from a potential underground nuclear explosion which could generate false alarms under a future Comprehensive Test Ban Treaty.

\section{Acknowledgments}

We especially thank the field technicians, Don Rock and Pat Lewis, who were responsible for installing and maintaining the seismometers. It was due to their hard work that this experiment was so successful. We also thank Rocky Thomson, Gary Buchan and all the people at the Cyprus Amax Twentymile Coal Company for their co-operation and assistance during this experiment. Steve Jarpe graciously provided assistance and codes for extracting the data from the field tapes. Kevin Mayeda kindly applied his regional coda algorithm to estimate the magnitude of the 
mining induced events. François Heuze first suggested looking at the Twentymile mine for collapse events, made the inital contacts, and provided aerial photos of the region. We thank Howard Patton for helpful discussions during the design of the experiment and subsequent analysis of the data. This work was performed under the auspices of the U.S. Department of Energy by the Lawrence Livermore National Laboratory under contract W-7405-ENG-48.

\section{References}

Mayeda, K. M., and W. R. Walter, (1996). Source parameters of western U.S. earthquakes: moment, energy, stress drop and source spectra from regional coda envelopes, J Geophys Res., (in press).

Mayeda, K. M. and W. R. Walter, (1995). Lg coda moment rate spectra and discrimination using Lg coda envelopes, Proceedings: Symposium on the NonProliferation Experiment: Results and Implications for Test Ban Treaties, DOE, LLNL Conf-9404100, sec. 6, 202-212, 1995

Pechmann, J. C., W. R. Walter, S. J. Nava and W. J. Arabasz, (1995). The February 3, $1995 \mathrm{ML}=5.1$ seismic event in the trona mining district of southwestern Wyoming, Seism. Res. Lett., 66, 25-34.

Prodehl, C. (1979). Crustal structure of the western United States, U.S. Geological Survey Professional Paper 1034, 74 pp.

Taylor, S. R. (1994). False alarms and mine seismicity: an example from the Gentry Mountain mining region, Utah, Bull Seism. Soc. Am. 84, 350-358.

Walter, W. R. (1993), Source parameters of the June 29, 1992 Little Skull Mountain earthquake from complete regional waveforms at a single station, Geophys Res Lett., $20,403-406$.

Walter, W. R., K. M. Mayeda and H. J. Patton, (1995). Phase and spectral ratio discrimination between NTS earthquakes and explosions Part1: empirical observations, Bull Seism. Soc. Am., 85, 1050-1067. 
Appendix A - Events to be studied

Date and Time of the Larger Events:

08/03/95 11:34

08/04/95 11:20

08/04/9511:29

08/04/95 11:55

08/04/95 11:56

08/04/95 11:58

08/05/95 23:28

08/05/95 23:29

08/05/95 23:31

08/08/95 04:29

08/08/95 04:30

08/08/95 17:44

08/08/95 17:47

08/08/95 17:48

08/08/95 19:51

08/14/95 11:54

08/14/95 12:00

08/14/95 12:15

08/14/95 12:18

08/15/95 01:58

08/19/95 19:53

08/24/95 04:28

08/24/95 11:14

08/24/95 11:16

08/24/95 11:45

08/24/95 13:05

08/24/95 13:35

08/24/95 15:19

08/24/95 17:19

08/25/95 12:51

08/25/95 16:14

08/27/95 $00: 30$

08/29/95 12:17

08/31/95 19:33

09/06/95 02:57

09/06/95 03:09
09/08/95 17:15

09/14/95 10:40

09/16/95 01:10

09/16/95 01:14

09/16/95 17:16

09/16/95 17:17

09/16/95 17:18

09/17/95 16:19

$09 / 17 / 9516: 20$

$09 / 17 / 9516: 21$

09/19/95 20:26

09/19/95 20:53

09/21/95 19:23

09/22/95 09:41

09/22/95 09:58

$09 / 24 / 9516: 29$

09/24/95 16:33

09/27/95 00:32

09/27/95 00:39

09/28/95 02:39

$09 / 28 / 9502: 41$ 


\section{Appendix B - Instrument locations}

\section{Close-in instruments}

Ground Zero (GZ)

Location - Directly over the expected center of the biggest event. The sensor is 200 meters south-east of the vent pipe, which is near at the north-west corner of the new panel.

Coordinates - N40 $20.952^{\prime}$. W $107^{\circ} 6.224^{\prime}$

Altitude $-7,106^{\prime}$

Estimated accuracy - 20 meters

Soil type - clay

Instrument - FBA-23

South site (S500M)

Location - 520 meters south and a little west of GZ.

Bearing to $\mathrm{GZ}-017^{\circ}$

Coordinates - N40 $20.683^{\prime} \mathrm{W} 107^{\circ} 6.335^{\prime}$

Altitude $-7,160^{\prime}$

Estimated accuracy -24 meters

soil type - easy digging at surface, clay at bottom of hole

Instrument - Wilcoxon piezoelectric accelerometer

East site (E500M)

Location- 490 meters east of GZ

Bearing to GZ - $270^{\circ}$

Coordinates - N40 $20.949^{\prime}$ W $107^{\circ} 5.880^{\prime}$

Altitude - 7,103'

Estimated accuracy - 21 meters

soil type - rock, shallow hole although

instruments are fully covered

Instrument - Wilcoxon piezoelectric

accelerometer
Location- 500 meters north of $\mathrm{GZ}$ Bearing to $\mathrm{GZ}-162^{\circ}$

Coordinates - N40 $21.208^{\prime} \mathrm{W} 107^{\circ} 6.330^{\prime}$

Altitude - 6,824'

Estimated accuracy - 22 meters soil type - clay and sandstone layers Instrument - Wilcoxon piezoelectric accelerometer

\section{Intermediate sites}

$5.5 \mathrm{~km}$ site (PD5KM)

Location- $5.88 \mathrm{~km}$ from GZ

Bearing to $\mathrm{GZ}-147^{\circ}$

Coordinates - N40 $23.607^{\prime}$ W107 $8.494^{\prime}$

Altitude $-6,954^{\prime}$

Estimated accuracy - 24 meters

soil type - clay' soil, rocks on surface

Instrument - S-6000 seismometer

$8 \mathrm{~km}$ site (PD8KM)

Location- $8.18 \mathrm{~km}$ from GZ

Bearing to $\mathrm{GZ}-144^{\circ}$

Coordinates - N40 $24.523^{\prime}$ W10709.616

Altitude - 6,522'

Estimated accuracy - 27 meters

soil type - heavy clay soil

Instrument - S-6000 seismometer

$10.5 \mathrm{~km}$ site (PD10K)

Location- $10.57 \mathrm{~km}$ from GZ

Bearing to GZ - $149^{\circ}$

Coordinates - N40 $25.834^{\prime}$ W $107^{\circ} 10.071^{\prime}$

Altitude - 6,653'

Estimated accuracy - 17 meters

soil type - dry clay soil

Instrument - S-6000 seismometer

North site (N500M) 


\section{Distant Sites}

Pinedale $20 \mathrm{~km}$ site (PD20K)

Location-19.24km from GZ

Bearing to $\mathrm{GZ}-144^{\circ}$

Coordinates - N40²9.376 W107 $14.196^{\prime}$

Altitude - 6,594'

Estimated accuracy - 24 meters

soil type - heavy clay soil

Instrument - Guralp 40T seismometer

Pinedale $100 \mathrm{~km}$ site (PD100)

Location-99.91km from GZ

Bearing to $\mathrm{GZ}-140^{\circ}$

Coordinates - N41ㅇ․ $228^{\prime}$ W10751.624'

Altitude $-6,251^{\prime}$

Estimated accuracy - 19 meters

soil type - heavy clay soil on rock outcrop

Instrument - Guralp ESP seismometer

Golden $20 \mathrm{~km}$ site (G20K)

Location-21.83km from GZ

Bearing to GZ - $290^{\circ}$

Coordinates - N40 $16.854^{\prime}$ W $106^{\circ} 51.770^{\prime}$

Altitude - 7,208'

Estimated accuracy - 21 meters

soil type - rock outcrop

Instrument - Guralp 40T seismometer 


\section{Directions to Sites}

\section{Close-in instruments}

The mine can be reached by driving south on Route County Road(RCR) 27 (aka. Twentymile Road), which intersects US Highway 40 a couple of miles east of Hayden, CO.

The close-in sites are located on land owned by Robert Perry and operated by Bill Rogers (970-879-2187). From the mine, drive back. north on RCR 27. Most of the way through the posted subsidence zone is a dirt road heading due west along the main power lines. Follow this road, which is the old county road, to the first road and gate on the left.

E500M - From the above gate, take the first left and continue up the hill. The station is located about 5 meters from the road on the left side just below the bulldozed pad at the top of the first hill.

GZ - From the above gate, go to the right and down the hill, through the next gate. On the top of the hill is a silver gate on the left. Go through the gate and follow the (faint) tire tracks. The site is just to the right of the tracks where they meet the sagebrush. This site is 200 meters southeast of the mine vent pipe.

S500M - Continue from GZ on the tire tracks up the hill, down across the small creek, and along the fence. The site is about 10 meters from the fence line.

N500M - There is a red gate just south of where RCR 27 crosses Fish creek. Go through this gate and the woven wire gate about 40 meters along the "road." Follow the bottom land over to where the "road" heads up the hill near the fence line. The site is just above the edge of old river cut.

\section{Intermediate sites}

PD5KM - Continue north on RCR 27 from the mine. Near the top of a hill, there is a double wide gate on the left (west) side with a well graded dirt road. The site is about 80 meters past the gate, down the hill on the left side, next to a clump of bushes.

PD8KM - Continue north on RCR 27 from the mine. About 150 meters before a large pond is a double wide green gate with a combination lock. Follow the ranch road almost a mile. Turn left (west) on a very faint ranch road just past the dam of another pond. Continue to the fence and turn left. The site is located ahead on the flat.

PD10K - Continue north on RCR 27 from the mine to RCR 51D. This dirt road is not marked 
and can be difficult to spot. It is on the left (west) next to an old wooden building. Follow this road until it crosses a small creek and turns sharply to the right (north). Turn left (south) before the creek (east side) and drive cross country about 250 meters to an outside corner of a fence. The site is within 10 meters of this corner.

\section{Distant Sites}

PD20K - This site is on the Yampa Valley (Hayden) Airport property. Stop at the old terminal building, go through the old waiting area and up the stairs at the back. The manager is Dave Bravdica (970-276-3669). He can give permission to visit the site, which is located about 100 meters north of the west end of the runway. There is a dirt road near the end of the taxiway which leads to an electrical shack. Our site is about 100 meters beyond the shack.

PD100 - Take Colorado Route 13 north from Craig past Baggs, WY. Turn left (west) 0.7 miles after crossing the Little Snake River. This is the last road for a while and located on the edge of town. The site is $17.42 \mathrm{~km}$ west of where this dirt road leaves the highway. The site is on the left (south) side of the road on a small finger of the mesa, before the road drops down to the river below. This site may be difficult to find without a GPS receiver. Some branches of the road are best identified by using a compass and choosing the route that leads west.

G20KM - This site is located in the Stagecoach State Recreation Area (SSRA). Take US 40 south from Steamboat Springs to State route 131. Continue south on 131 to road 14, and then south on road 14 to SSRA on the left (east) side of the road. Follow the park road around to the right to the ranger headquarters building. It would be best to check in with Ranger Wayne. The site is reached from the back parking lot of the ranger building. Walk up the hill along the south end of the sewage ponds. The site is just past the rock outcropping at the top of the hill. 


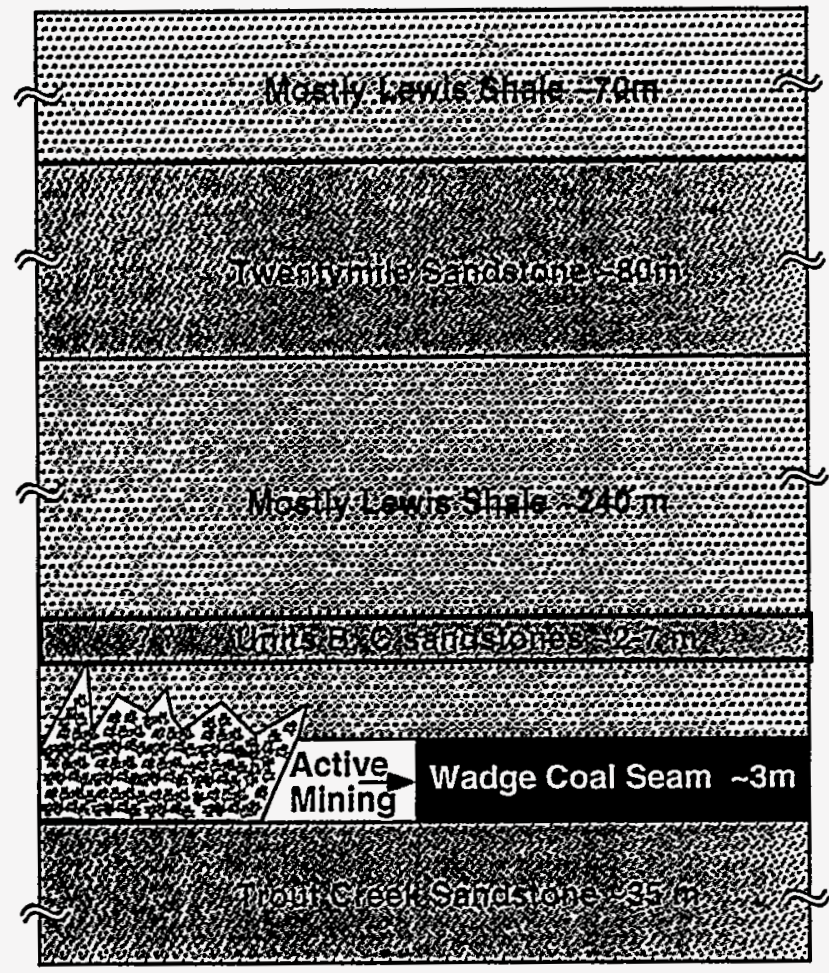

Fig 1. Simplified schematic cross section of Twentymile coal mine and some of the major rock units. The $3 \mathrm{~m}$ (10 ft.) high Wadge coal seam is completely excavated within the mining panels and the weak shale rocks are allowed to collapse behind the advancing face of active mining. It is hypothesized that the roof rock collapses until it reaches the stronger sandstone rock layers which can support more weight before failure. We believe it is the failure of these sandstone layers, either units $\mathrm{B}, \mathrm{C}$ or the thicker Twentymile sandstone layers that are responsible for the largest seismic events. (Simplified from detailed cross sections provided by Twentymile coal mine).

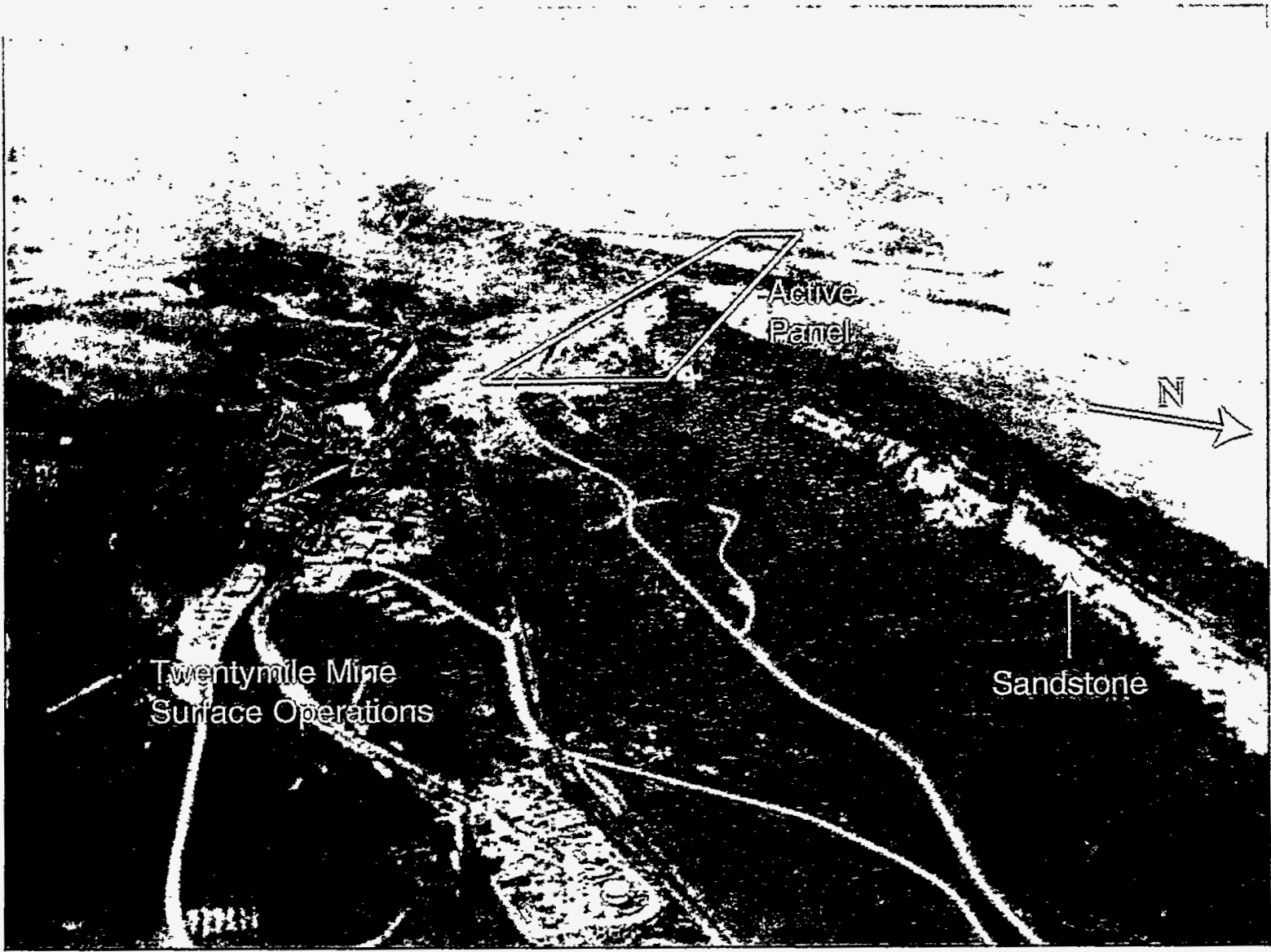

Fig. 2. Aerial photo of Twentymile Coal Mine area. A surface projection of the currently active mining panel is superimposed on the picture. The ground above the active panel and previously mined panels to the north has subsided $4.5 \mathrm{~m}$ but this is not easily visible to the naked eye. The Twentymile sandstone layer is visible where it outcrops. (Photo courtesy of François Heuze). 


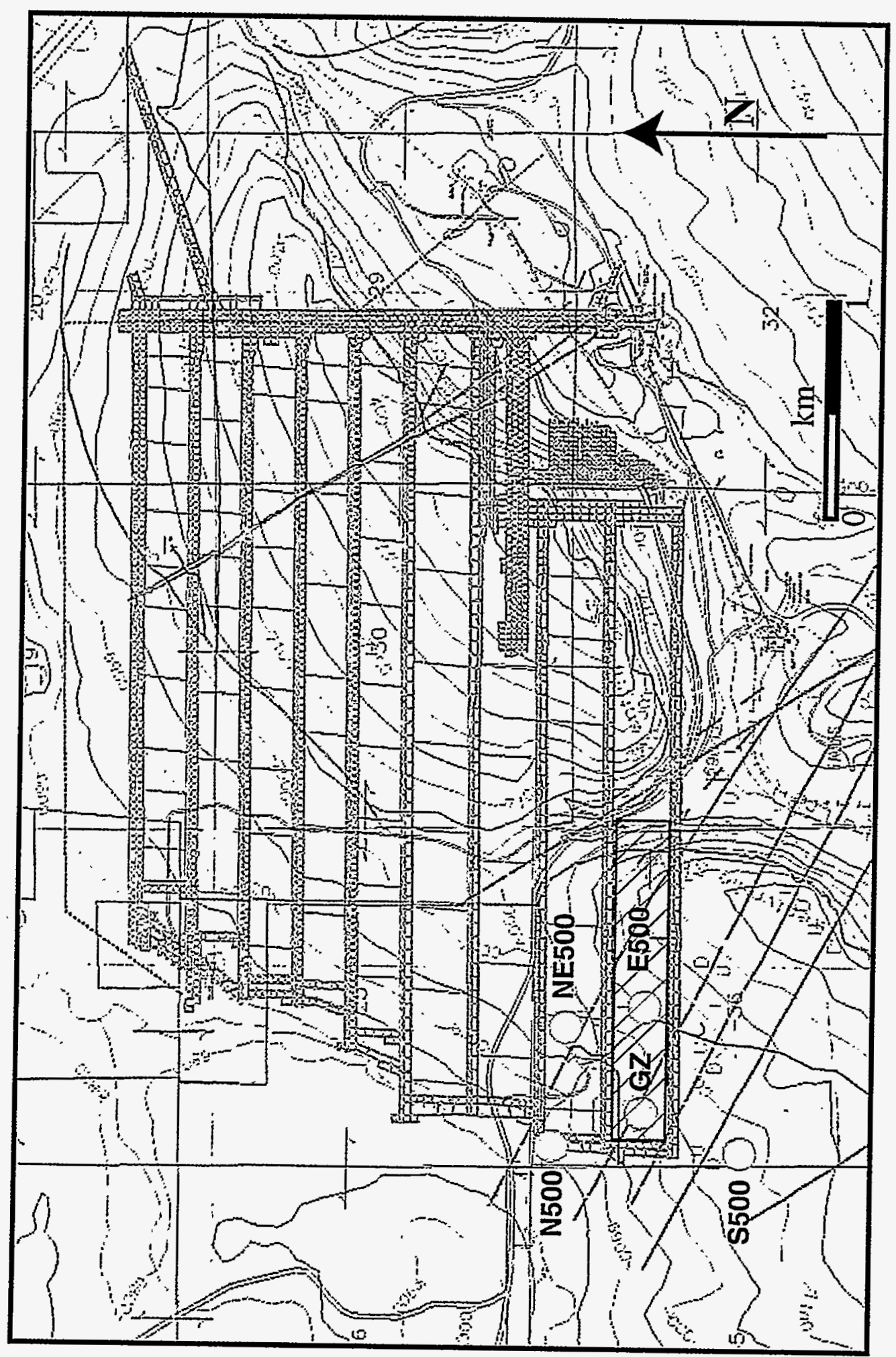

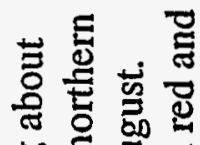

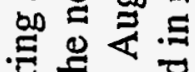

品

.

号速

율 馬

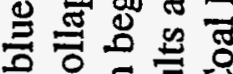

응

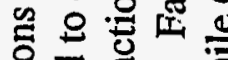

试 롤

৬

.령

怘 令 至

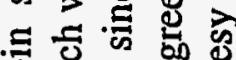

ঠั่

은 융

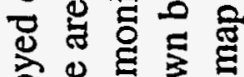

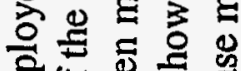

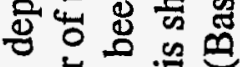

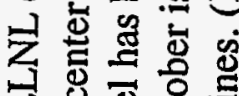

어율

म

ㅇㅇㅇㅎㅎ응

공영

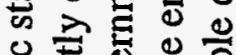

.려웛월

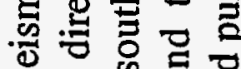

๘

音焉

\& 으 행

어욜

윯

苛 응 突

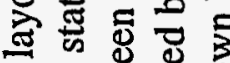

๖ 운.

总过 글

4 엉웡

3 ㅎํ을

式方焉

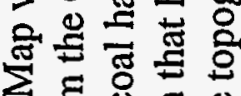

之

r 은

Ð ઘ ๘

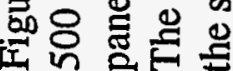




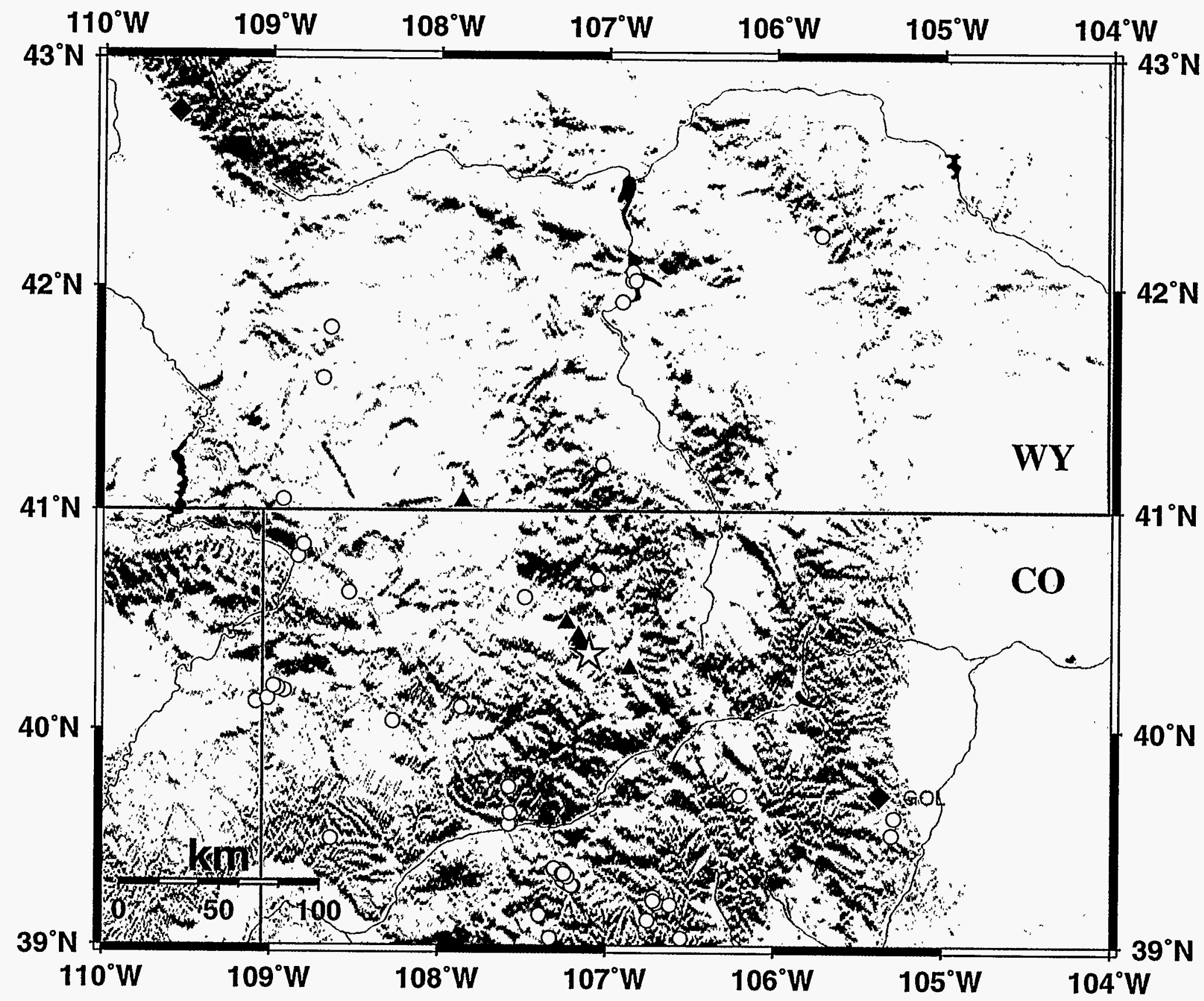

趈 Mine

○ Seismiçity

$\Delta$ Deployed Station

- Existing Station

Topography (m)

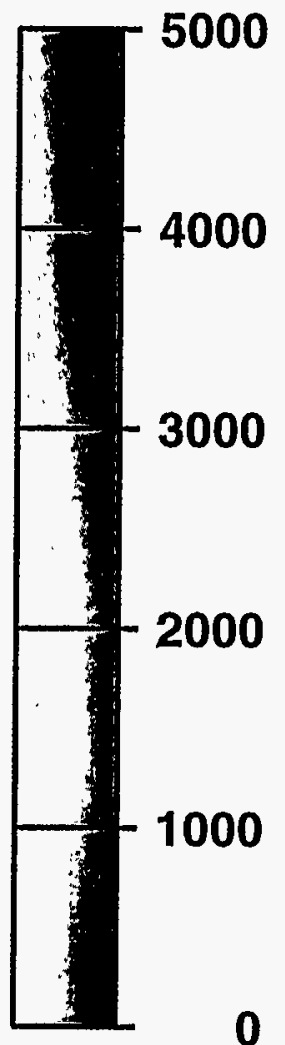

Fig. 4. Map showing location of mine, seismic stations, past seismicity and topography. 

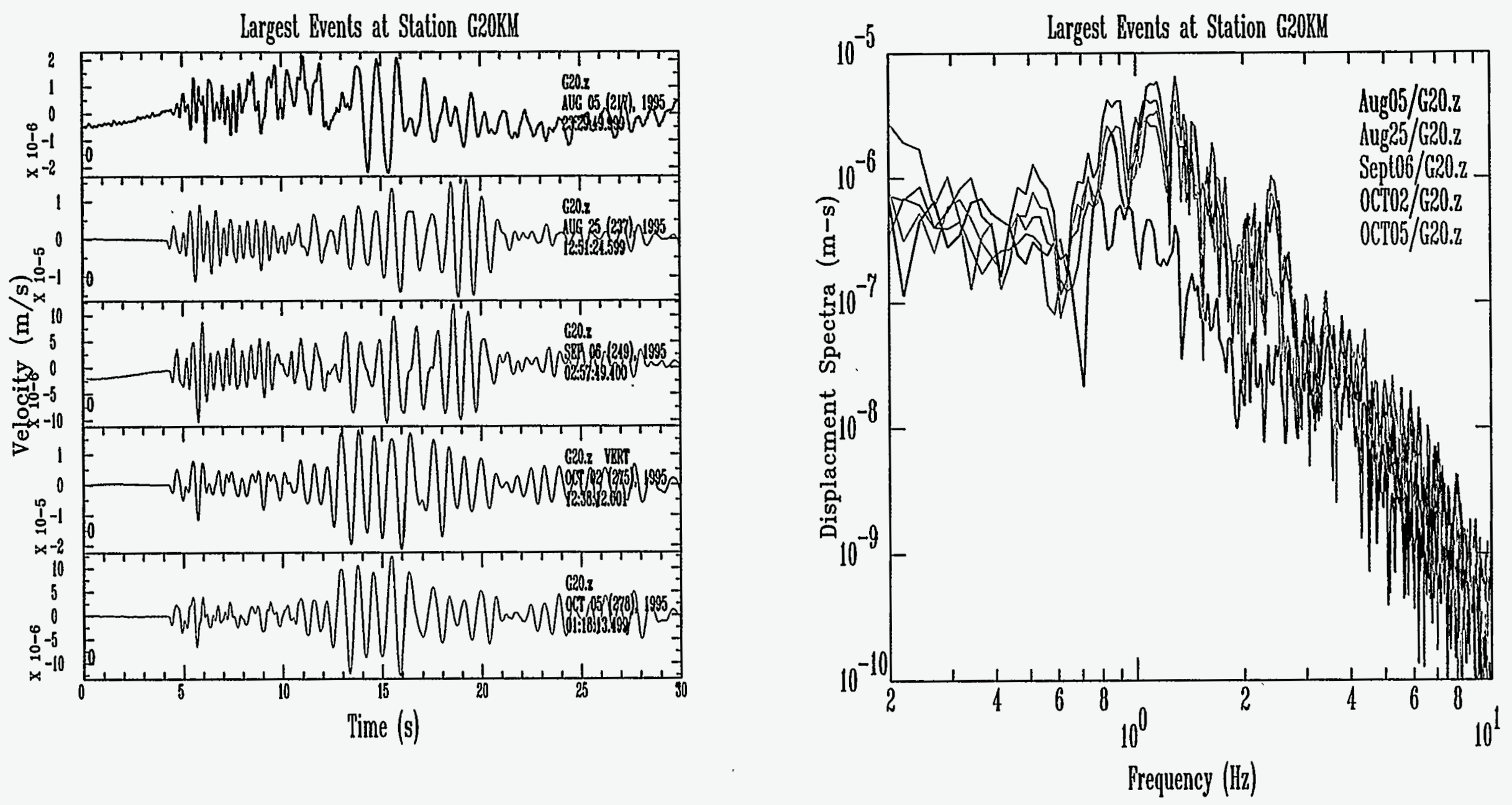

Fig. 5. A comparison of the seismograms and spectra of the five largest mining induced events recorded $20 \mathrm{~km}$ away at station $\mathrm{G} 20 \mathrm{~km}$. On the left, the velocity seismograms of the five different events show many similarities. In particular note the resemblance of the Sept 6 th event to that of August 25th and of the October 5th to the October 2nd. All the events are dominated by an approximately $1 \mathrm{~Hz}$, slowly traveling $\mathrm{Rg}$ phase (arriving after $12 \mathrm{~s}$ or a group velocity $<1.7 \mathrm{~km} / \mathrm{s}$ ), commonly observed at local distances from very shallow events. On the right hand side the displacement spectra are shown for the frequency band with signal above the noise. Note that all except the August 5th event show a peak near $1 \mathrm{~Hz}$. The spectra from the five events also share many similarities but note that while the August 5th event (black trace) has a similar long-period level to the others it appears deficient in high frequencies. 
Foidel Creek event on $8 / 25 / 95$ at close-in stations

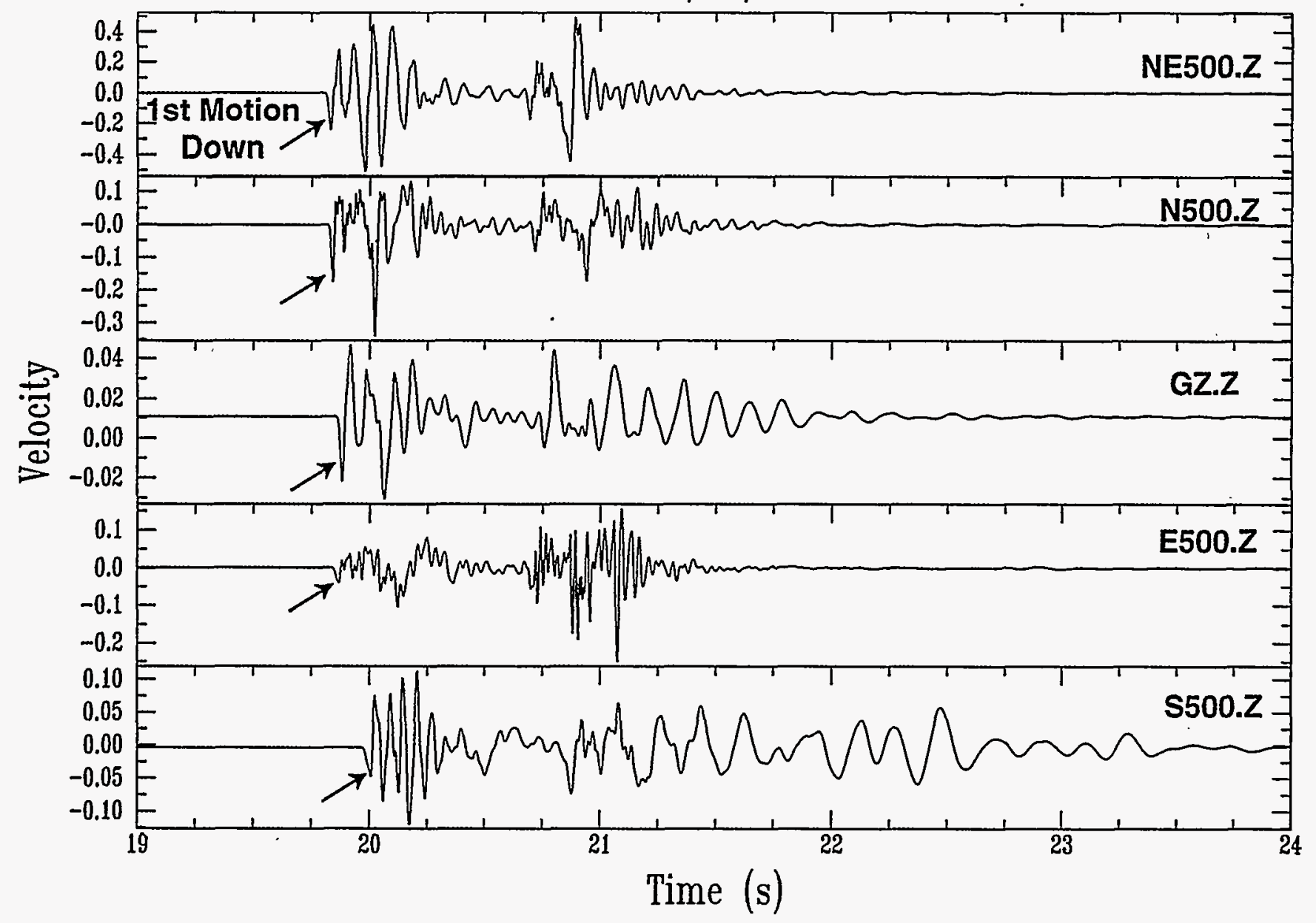

Fig. 6. Close-in accelerometer records of the $\mathrm{ML}=2.8$ event on August 25, 1995 at the Twentymile Coal Mine at Foidel Creek, $\mathrm{CO}$. Note the first motions are down (negative velocity) on all five stations. This indicates the ground initially sank beneath all the stations during the event. This type of motion is consistent with a large collapse or a very shallow normal-faulting earthquake. Notice also the complexity of the traces, and the variation between these very closely located stations. Part of this complexity may be due to strong variations in the geology and structure beneath the stations. For example, sites NE500 and N500 are located above a panel which has already been mined and the ground has subsided. The remainder of the complexity is most likely due to the source and may indicate that at high frequencies the event is composed of several sources which may vary in time, location and mechanism. 

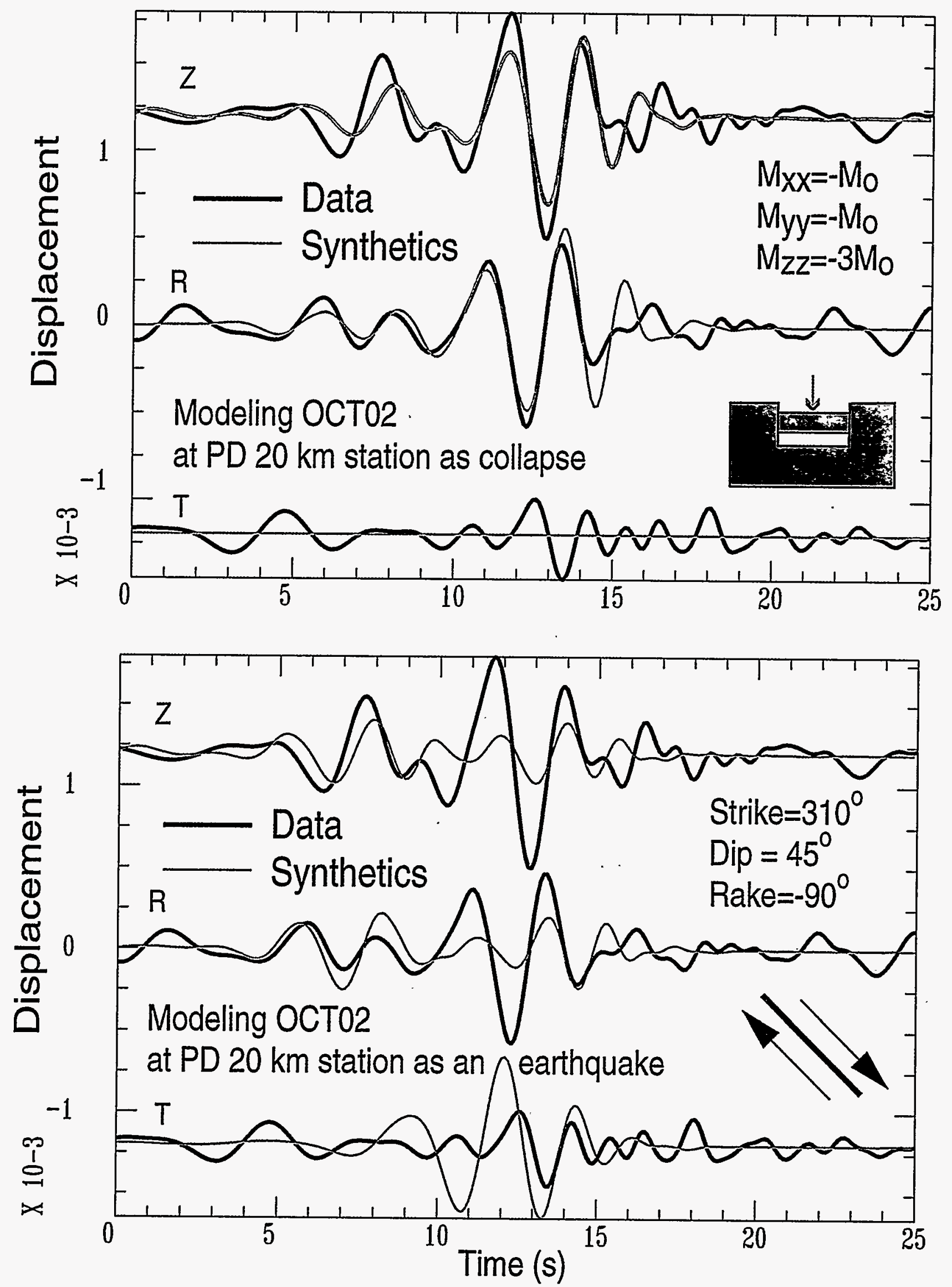

Fig. 7. Preliminary waveform modeling indicates the point-source mechanism for the largest events are more consistent with a gravitational collapse mechanism than a normal earthquake mechanism. This example shows 3 component, $2-5 \mathrm{~s}$ period fits of synthetic seismograms for both mechanism types to the data recorded at a station $20 \mathrm{~km}$ away towards Pinedale (PD20KM). 


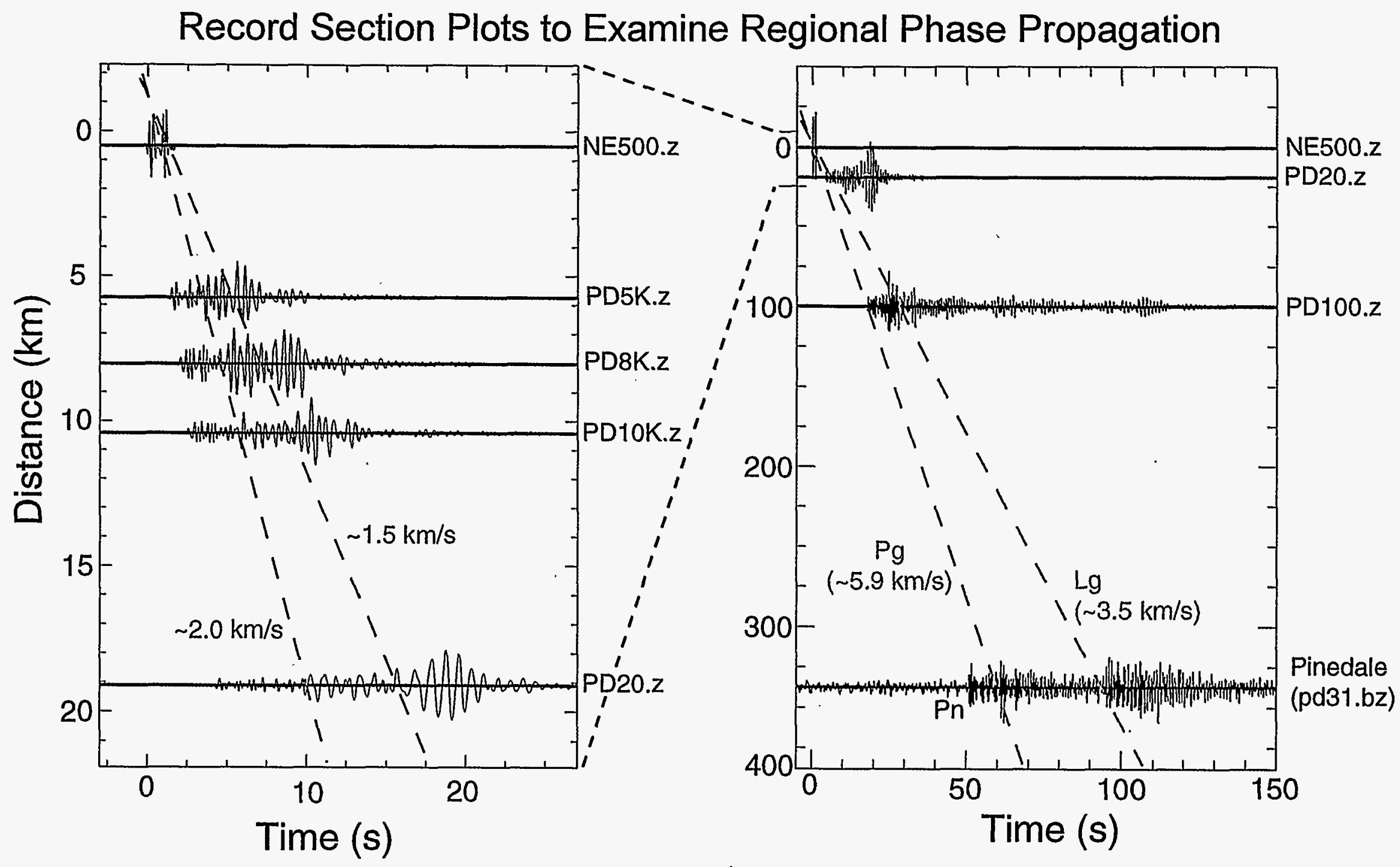

Fig. 8. Local and regional vertical component seismograms from $M L=2.8$ Foidel Creek, $C O$ event on 8/25/95 plotted as a function of distance. The stations deployed by LLNL along a line from the Twentymile Coal Mine to the Primary array station at Pinedale, WY allow the study of the evolution and propagation characteristics of the the regional phases used for event identification. This can improve our physical understanding of how and why regional phase discriminants work at the actual monitoring station at Pinedale. At the close-in stations note the large amplitude very late arriving surface wave energy with very slow apparent velocities $<1.5-2.0 \mathrm{~km} / \mathrm{s}$. At more regional stations the Pg phase shows up clearly while the $\mathrm{Pn}$ and $\mathrm{Lg}$ phases do not separate out clearly until the Pinedale station. 


\begin{tabular}{|c|c|c|}
\hline Ahern, Timothy & Flatte, Stanley & Massinon, Bernard \\
\hline Ahrens, Thomas J. & Frankel, Arthur & Mayeda, Kevin \\
\hline Aki, Keiiti & Garbin, Douglas & McCartor, Gary \\
\hline Alexander, Shelton & Given, Holly & McCormack, David \\
\hline Ammon, Charles & Given, Jeffrey W. & McEvilly, Thomas V. \\
\hline Anderson, Douglas & Glenn, Lewis A. & McGarr, Art \\
\hline Archambeau, Charles B. & Goldstein, Peter & McLaughlin, Keith L. \\
\hline Archuleta, Ralph & Grant, Lori T. & McNally, Karen \\
\hline Baker, Glenn Eli & Gupta, Indra N. & McNamara, Dan \\
\hline Barazangi, Muawia & Gustafson, Richard & Mechler, Pierre \\
\hline Bardzell, Richard J. & Hagedorn, Dan & Menke, William \\
\hline Barker, Jeffery & Hannon, Wilard J. & Minster, Jean-Bernard \\
\hline Basham, Peter & Harben, Phillip & Mitchell, Brian J. \\
\hline Baumgardt, Douglas $R$. & Harjes, Hans-Peter & Moran, Bill \\
\hline Beck, Susan & Harkrider, David & Morrow, Richard J. \\
\hline Bennett, Theron J. & Harris, Dave & Mykkeltveit, Svein \\
\hline Berger, Jonathan & Harvey, Danny & Nakanishi, Keith K. \\
\hline Blandford, Robert & Hedlin, Michael & $\mathbf{N i}$, James \\
\hline Bouchon, Michel & Helmberger, Donald V. & North, Robert G. \\
\hline Bratt, Steve R. & Henger, Manfred & Orcutt, John A. \\
\hline Breding, Dale $\mathrm{R}$. & Herrin, Eugene T. & Owens, Thomas J. \\
\hline Brune, J. & Herrington, Preston $B$. & Passow, Richard \\
\hline Burdick, Lawrence & Herrmann, Robert & Patton, Howard J. \\
\hline Burkhard, Norman & Heuze, François & Phinney, Robert A. \\
\hline Campillo, Michel & Hsu, Vindell & Pomeroy, Paul \\
\hline Carr, Dorothe & Husebye, Eystein S. & Priestley, Keith \\
\hline Carrigan, Charles & Hutchings, Larry & Prothero, William \\
\hline Carter, Jerry A. & Israelsson, Hans & Pulli, Jay J. \\
\hline Casey, Leslie A. & Jarpe, Stephen & Randall, George \\
\hline Chan, Winston & Jih, Rong-Song & Reinke, Robert E. \\
\hline Chun, Kin-Yip & Johnson, Lane $\mathrm{R}$ & Richards, Paul G. \\
\hline Cipar, John J. & Jordan, Thomas H. & Ringdal, Frode \\
\hline Cogbill, Allen $\mathrm{H}$. & Kadinsky-Cade, Katharine & Rivers, Wilmer \\
\hline Comer, Robert & Kafka, Alan & Rodgers, Arthur \\
\hline Cormier, Vernon F. & Keller, Randy & Rodgers, Peter W. \\
\hline Dainty, Anton W. & Kennett, Brian L. N. & Rohay, Alan C. \\
\hline Day, Steven M. & Kisslinger, Carl & Romanowicz, Barbara \\
\hline Denny, Marv & Knowles, Skip & Rothe, George $\mathrm{H}$. \\
\hline Der, Zoltan A. & Korhonen, Heikki & Russell, David R. \\
\hline Dickinson, Stanley K. & Kvaerna, Tormod & Ryall, Alan S. \\
\hline Doser, Diane I. & Ladd, Anthony & Saikia, Chandan $\mathrm{K}$. \\
\hline Douglas, Alan & Langston, Charles & Sammis, Charles G. \\
\hline Farrell, William & Lay, Thorne & Schlittenhardt, Joerg \\
\hline Fehler, Michael C. & Leith, William & Schult, Frederick \\
\hline Ferguson, John & Linger, Don & Schwartz, Susan I \\
\hline iisk, Mark D. & Malin, Peter & Se \\
\hline
\end{tabular}


Shapira, Avi

Simpson, David

Smith, Albert $T$.

Stevens, Jeffrey L.

Stump, Brian

Swanger, Henry J.

Sweeney, Jerry

Sykes, Lynn

Taylor, Steven $R$.

Teng, Ta-liang

Toksoz, M. Nafi

Turnbull, Lawrence

Van der Vink, Gregory

Velasco, Aaron

Vernon, Frank L.

Wallace, Terry C.

Walter, William $\mathrm{R}$.

Weaver, Thomas $T$.

$\mathrm{Wu}$, Francis T.

Zollweg, James

Zucca, Jay 


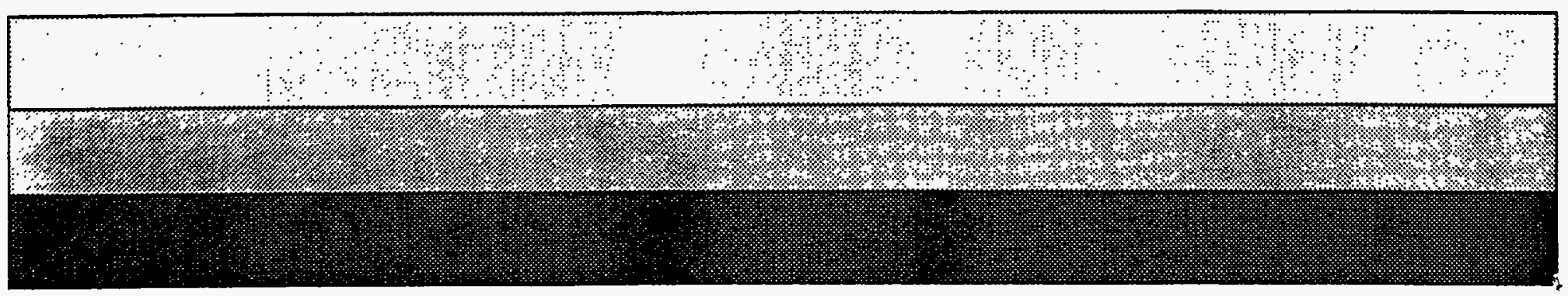

